Article

\title{
Comparison of the Effects of Fucoidans on the Cell Viability of Tumor and Non-Tumor Cell Lines
}

\author{
Kaya Saskia Bittkau ${ }^{1, \dagger}$, Philipp Dörschmann ${ }^{2,+}$, Martina Blümel ${ }^{3}{ }^{\mathbb{C}}$, Deniz Tasdemir ${ }^{3,4} \mathbb{C}$, \\ Johann Roider ${ }^{2}$, Alexa Klettner ${ }^{2, *,+}$ and Susanne Alban ${ }^{1, *,+}$ \\ 1 Pharmaceutical Institute, Kiel University, Gutenbergstraße 76, 24118 Kiel, Germany \\ 2 Department of Ophthalmology, University of Kiel, University Medical Center, Arnold-Heller-Str. 3, Haus 25, \\ 24105 Kiel, Germany \\ 3 GEOMAR Centre for Marine Biotechnology (GEOMAR-Biotech), Research Unit Marine Natural Products \\ Chemistry, GEOMAR Helmholtz Centre for Ocean Research Kiel, Am Kiel-Kanal 44, 24106 Kiel, Germany \\ 4 Faculty of Mathematics and Natural Sciences, Kiel University, Christian-Albrechts-Platz 4, \\ 24118 Kiel, Germany \\ * Correspondence: alexakarina.klettner@uksh.de (A.K.); salban@pharmazie.uni-kiel.de (S.A.); \\ Tel.: +49-431-5002-4283 (A.K.); +49-43-1880-1135 (S.A.) \\ + These authors contributed equally to the work.
}

Received: 26 June 2019; Accepted: 23 July 2019; Published: 26 July 2019

check for updates

\begin{abstract}
Fucoidans extracted from brown algae exert manifold biological activities paving the way for the development of numerous applications including treatments outside tumor therapy such as age-related macular degeneration or tissue engineering. In this study, we investigated the antiproliferative effects of fucoidans extracted from six different algae (Fucus vesiculosus, F. serratus, F. distichus subsp. evanescens, Dictyosiphon foeniculaceus, Laminaria digitata, Saccharina latissima) as well as three reference compounds (Sigma fucoidan, heparin, enoxaparin) on tumor (HL-60, Raji, HeLa, OMM-1, A-375, HCT-116, Hep G2) and non-tumor (ARPE-19, HaCaT) cell lines. All fucoidans were extracted according to a standardized procedure and tested in a commercially available MTS assay. Cell viability was measured after $24 \mathrm{~h}$ incubation with test compounds $(1-100 \mu \mathrm{g} / \mathrm{mL})$. Apart from few exceptions, fucoidans and heparins did not impair cell viability. In contrast, fucoidans significantly increased cell viability of suspension cell lines, but not of adherent cells. Fucoidans slightly increased viability of tumor cells and had no impact on the viability of non-tumor cells. The cell viability of HeLa and ARPE-19 cells negatively correlated with protein content and total phenolic content (TPC) of fucoidans, respectively. In summary, none of the tested fucoidans turned out to be anti-proliferative, rendering them interesting for future studies and applications.
\end{abstract}

Keywords: Fucus vesiculosus; Fucus serratus; Fucus evanescens; Laminaria digitata; Saccharina latissima; Dictyosiphon foeniculaceus; heparin; cancer; cytotoxic; antiproliferative

\section{Introduction}

Cancer is one of the leading causes of death in industrial nations and a wide variety of types of cancer exists. Despite enhanced research interest and already existing medical treatments, the mortality rate is still very high, depending on the cancer type. A common complication in cancer patients and one of the leading causes of death is venous thromboembolism (VTE) [1]. The first choice in the prevention and treatment of cancer-associated thrombosis (CAT) is low molecular weight heparins (LMWH) [2,3]. Several clinical trials and meta-analyses have concluded that the use of LMWH may improve overall survival in cancer patients, particularly in those with early stage disease [4]. Although this clinical benefit still needs to be proven by sufficiently powered studies, a wealth of experimental 
data supports the antitumor and antimetastatic activities of heparins, whereby manifold mechanisms may be involved [5-7]. However, major obstacles to a potential use of heparins as anticancer drugs are their high bleeding risk and their animal origin, which is associated with resource limitations as well as contrary to the precautionary principle [8].

A potential alternative may be fucose-containing sulfated polysaccharides, the so-called fucoidans, extracted from brown algae. Fucoidans display an attractive array of bioactivities and potential applications including not only cancer inhibition, but also immune modulation, pathogen defense and numerous others (e.g., influence on elastase and collagenase with regard to inhibition of skin aging, treatment of inflammation as well as liver and kidney health) [9,10]. Many of their pharmacological effects may contribute to their antitumor and antimetastatic activities observed in animal experiments [11,12]. A substantial advantage of fucoidans over heparins is their relatively weak anticoagulant activity and thus low bleeding risk, whereas many of their other effects are stronger than those of heparins [13-15].

In general, one of the pivotal initial in vitro tests is the examination of the influence of potentially active agents such as fucoidans on cell viability. Whereas antiproliferative effects on tumor cell lines are favorable for antitumor therapies, cytotoxicity on non-cancerous cells is a big limitation for any lead compound, including fucoidans. Such toxicity may hamper other potential applications of fucoidans, for example their use in tissue engineering for improvement of bone vascularization during bone repair $[16,17]$. Another attractive field is cosmetics, as fucoidans have been described to stimulate the proliferation of dermal fibroblasts and inhibit enzymes that degrade the extracellular matrix [9]. Even in ophthalmology, fucoidans are of interest for their favorable effects for the treatment of age-related macular degeneration (AMD) $[18,19]$.

Plenty of in vitro studies have been published describing antiproliferative or cytotoxic effects of fucoidans, especially on tumor cell lines. For example, Saravana et al. recently reported that a fucoidan from Saccharina japonica inhibited the proliferation of human myeloma and T-cell lymphoma cells as well as having cell growth inhibitory effects on SH-SY-5Y (neuroblastoma cells) and MKN-28 (adenocarcinoma cells) [20]. Jiang et al. showed the cytotoxic effect of a fucoidan from Ascophyllum nodosum on XC (rat sarcoma) and Vero cells (African green monkey kidney) using colony formation assay [21]. Moreover, fucoidans have been reported to induce apoptotic signaling pathways [11,22-25].

According to literature, the first commercially available fucoidan (Fucus vesiculosus) from Sigma-Aldrich is one of the most widely examined fucoidans. Interestingly, it has been shown to have divergent effects depending on the cell line used. For example, neither toxic nor antiproliferative effects were demonstrated when testing porcine or human retinal pigment epithelium (RPE) [18], whereas the cell viability of human colon cancer cells (HT29) decreased by incubation with fucoidan (Fucus vesiculosus) from Sigma-Aldrich [26].

Another reason for the conflicting published effects of fucoidans on cell viability is the high variability of experimental designs concerning e.g., incubation time, type of assay and applied concentrations. Especially the latter varies by several orders of magnitude $[27,28]$. Testing high concentrations $(>100 \mu \mathrm{g} / \mathrm{mL})$ may be relevant for special applications such as topical use or tissue engineering [29]. However, it has to be considered that biological effects of very high fucoidan concentrations may just represent laboratory artefacts, e.g., caused by high viscosity, binding and neutralizing of serum components or even limited solubility.

Further, it has to be considered that the most frequently tested commercial fucoidan had pronounced batch variability in the past and its effects on cell viability correlated with its purity [14]. Finally, only a few studies compared the effects of fucoidans from different brown algal species $[20,27,29,30]$ on cell viability so far, whereby the observed differences may sometimes result from different extraction and purification procedures, rather than the use of different algal material.

In the present study, we tested the cell viability effects of six fucoidans on nine different cell lines. The fucoidans were extracted from six different brown algal species by using the same extraction method. Cell viability effects were assessed using one standardized assay enabling direct comparison 
of the results. The extracted algal species were Fucus vesiculosus, F. serratus, F. distichus subsp. evanescens, Dictyosiphon foeniculaceus, Laminaria digitata and Saccharina latissima resulting in the fucoidans named FV, FS, FE, DF, LD and SL. Among the nine cell lines were two suspension cell lines (HL-60 (acute myeloid leukemia), Raji (Burkitt lymphoma)) and seven adherent cell lines [HeLa (cervix carcinoma), ARPE-19 (human RPE), OMM-1 (uveal melanoma), A-375 (skin melanoma), HCT-116 (colon carcinoma), Hep G2 (hepatocellular carcinoma), HaCaT (keratinocytes)], thus including a total of seven tumor cell lines (HL-60, Raji, HeLa, OMM-1, A-375, HCT-116, Hep G2) and two non-cancerous cell lines (ARPE-19 and $\mathrm{HaCaT})$. After incubation for $24 \mathrm{~h}$ with the different fucoidans, the cell viability was measured using a commercial MTS assay according to a standardized protocol. As reference compounds three different commercially available substances, namely reference heparin as well as reference enoxaparin (a LMWH) and the commercial Fucus vesiculosus fucoidan, were additionally tested. The tests were performed to obtain comparative information on the suitability of the different fucoidans for further investigations.

\section{Results}

The details of the extraction procedure of the six fucoidans as well as their basic characteristics namely degree of sulfation (DS), molecular mass, monosaccharide composition, their contents of polyphenols, laminarin and protein as well as their radical-scavenging capacity, three exemplary bioactivities and their fluorescence intensity (FI) increasing effect on the sulfated glycan sensor Polymer-H are described elsewhere (unpublished data until accepted). To compare the effects of the different fucoidans and reference substances on cell viability, we determined their effects at concentrations up to $100 \mu \mathrm{g} / \mathrm{mL}$ (i.e., $0.07-0.53 \mu \mathrm{M}$ fucoidans and 2.00 $\mu \mathrm{M}$ Sigma fucoidan, $7.69 \mu \mathrm{M}$ heparin and $28.57 \mu \mathrm{M}$ enoxaparin, whereby the molar concentrations can, however, only be very roughly estimated due to the polydispersity of these polysaccharides) on nine different cell lines in relation to the untreated control (100\%) (Figure 1).

In the leukemic cell line HL-60, all test compounds apart from the DF fucoidan increased the cell viability (Figure 1a). The effects of FE and SL were significant at all concentrations. FV, FS and LD increased the cell viability significantly at concentrations $>1 \mu \mathrm{g} / \mathrm{mL}$. Sigma fucoidan had stimulating effects at concentrations of 50 and $100 \mu \mathrm{g} / \mathrm{mL}(p<0.05)$, heparin only at $50 \mu \mathrm{g} / \mathrm{mL}(p<0.05)$ and the LMWH enoxaparin only at $100 \mu \mathrm{g} / \mathrm{mL}(p<0.001)$. A questionable exception was the significant lower cell viability $(77.7 \pm 11.0 \%, p<0.01)$ after treatment with $10 \mu \mathrm{g} / \mathrm{mL}$ enoxaparin, whereas $100 \mu \mathrm{g} / \mathrm{mL}$ increased the cell viability significantly $(p<0.001)$. The commercial fucoidan had a stimulating effect at 50 and $100 \mu \mathrm{g} / \mathrm{mL}(p<0.05)$.

In the Burkitt lymphoma cell line Raji, no inhibitory but rather a stimulatory effect was observed (Figure 1b). FV and FS fucoidans significantly increased the cell viability at 10, 50 and $100 \mu \mathrm{g} / \mathrm{mL}$ and FE only at $50 \mu \mathrm{g} / \mathrm{mL}(p<0.01)$. The other fucoidans and the reference substances showed no significant effect.

The cervical adenocarcinoma cell line HeLa was one of the four cell lines, in which the compounds partly reduced the cell viability (Figure 1c). This was most pronounced with the DF extract at all concentrations $(1 \mu \mathrm{g} / \mathrm{mL} 60.8 \pm 20.7 \%, p<0.01 ; 10 \mu \mathrm{g} / \mathrm{mL} 65.7 \pm 17.8 \%, p<0.01 ; 50 \mu \mathrm{g} / \mathrm{mL} 68.7 \pm 19.2 \%$, $p<0.01 ; 100 \mu \mathrm{g} / \mathrm{mL} 63.6 \pm 24.3 \%, p<0.05)$. FE fucoidan decreased the cell viability at $1 \mu \mathrm{g} / \mathrm{mL}(p<0.01)$. The reference substance heparin showed significant reduction in cell viability at concentrations of 50 and $100 \mu \mathrm{g} / \mathrm{mL}(p<0.001 ; p<0.01)$.

In the RPE cell line ARPE-19, both stimulation and reduction of the cell viability was found. FS fucoidan significantly decreased it in a concentration-dependent manner $(93.9 \pm 3.3 \%, p<0.001$; $90.9 \pm 2.6 \%, p<0.001 ; 87.4 \pm 8.7 \%, p<0.01 ; 79.3 \pm 14.7 \%, p<0.01$ ) (Figure $1 \mathrm{~d}$ ). In contrast, LD fucoidan concentration-dependently increased the cell viability $(50 \mu \mathrm{g} / \mathrm{mL} p<0.001 ; 100 \mu \mathrm{g} / \mathrm{mL} p<0.01)$. The cell viability of the ARPE-19 cells incubated with the other compounds was comparable to the untreated control, although some small changes turned out to be significant (Figure 1d).

Similar to ARPE-19 cells, the uveal melanoma cell line OMM-1 responded differently to the treatment with the compounds, whereby FE and DF led to concentration-dependent effects (Figure 1e). 
The cell viability was significantly decreased by FS and DF at $50(85.3 \pm 4.6 \%, p<0.001,87.1 \pm 11.9 \%$, $p<0.01)$ and $100 \mu \mathrm{g} / \mathrm{mL}(74.6 \pm 3.1 \%, p<0.001,74.3 \pm 13.2 \%, p<0.001)$ as well as by FE and SL at $100 \mu \mathrm{g} / \mathrm{mL}(86.3 \pm 8.8 \%, p<0.001,90.4 \pm 7.9 \%, p<0.01)$. Significant increase in the cell viability was observed for FV, LD and SL fucoidans at $10 \mu \mathrm{g} / \mathrm{mL}$. A trend of increase was further seen with heparin at concentrations of $1-50 \mu \mathrm{g} / \mathrm{mL}$.

In the skin melanoma cell line A-375 (Figure 1f) a significant increase of cell viability was observed for fucoidans from FE $(1 \mu \mathrm{g} / \mathrm{mL}, 105.8 \pm 1.9 \%, p<0.001$, and $100 \mu \mathrm{g} / \mathrm{mL}, 105.2 \pm 0.9 \%, p<0.001)$ as well as DF at the highest concentration $(100 \mu \mathrm{g} / \mathrm{mL}, 106.1 \pm 1.7 \%, p<0.001)$ and LD at the lowest concentration $(1 \mu \mathrm{g} / \mathrm{mL}, 107.6 \pm 2.0 \%, p<0.001)$. Of note, slightly significant reduction of cell viability for A-375 was measured only for SL ( $50 \mu \mathrm{g} / \mathrm{mL}, 96.5 \pm 2.6 \%$ and $100 \mu \mathrm{g} / \mathrm{mL}, 94.8 \pm 3.3 \%$, both $p<0.05$ ).

The colon carcinoma cell line HCT-116 treated with DF $(10 \mu \mathrm{g} / \mathrm{mL} 112.5 \pm 5.5 \%, p<0.01 ; 50 \mu \mathrm{g} / \mathrm{mL}$ $108.7 \pm 5.4 \%, p<0.05 ; 100 \mu \mathrm{g} / \mathrm{mL}, 111.9 \pm 3.8 \%, p<0.001)$ and LD $(50 \mu \mathrm{g} / \mathrm{mL}, 114.9 \pm 5.2 \%, p<0.001)$, as well as heparin at $100 \mu \mathrm{g} / \mathrm{mL}(p<0.001)$ showed significantly increased cell viability. Lower but still slightly significant increasing effects on cell viability were observed for fucoidans from FV $(100 \mu \mathrm{g} / \mathrm{mL}$, $p<0.01)$, FE $(50 \mu \mathrm{g} / \mathrm{mL}, p<0.05)$, SL at the lowest three tested concentrations $(1 \mu \mathrm{g} / \mathrm{mL}, p<0.05$; $10 \mu \mathrm{g} / \mathrm{mL}, p<0.01$ and $50 \mu \mathrm{g} / \mathrm{mL}, p<0.05)$. A slight, but significant increase in cell viability was also measured for the Sigma fucoidan at $10 \mu \mathrm{g} / \mathrm{mL}$ and $100 \mu \mathrm{g} / \mathrm{mL}, p<0.01$; heparin $100 \mu \mathrm{g} / \mathrm{mL}, p<0.05$ ).

The hepatocellular carcinoma cell line Hep G2 showed no significant change of viability after application of almost all reference compounds at all concentrations with one exception: enoxaparin at $1 \mu \mathrm{g} / \mathrm{mL}, p<0.01$. The same is true for DF fucoidan, for which no significant change of cell viability was observed at all test concentrations and also for SL, except an increase at the lowest test concentration $(p<0.05)$. A slightly significant increase in cell viability was however measured for fucoidans from all Fucus species, namely FV with increasing concentration $(50 \mu \mathrm{g} / \mathrm{mL}$ and $100 \mu \mathrm{g} / \mathrm{mL}$, both $p<0.05)$, FS at the two highest test concentrations $(50 \mu \mathrm{g} / \mathrm{mL}, p<0.05$ and $100 \mu \mathrm{g} / \mathrm{mL}, p<0.01), \mathrm{FE}(50 \mu \mathrm{g} / \mathrm{mL}$, $p<0.01)$ as well as LD $(1 \mu \mathrm{g} / \mathrm{mL}$ and $50 \mu \mathrm{g} / \mathrm{mL}$, both $p<0.01)$.
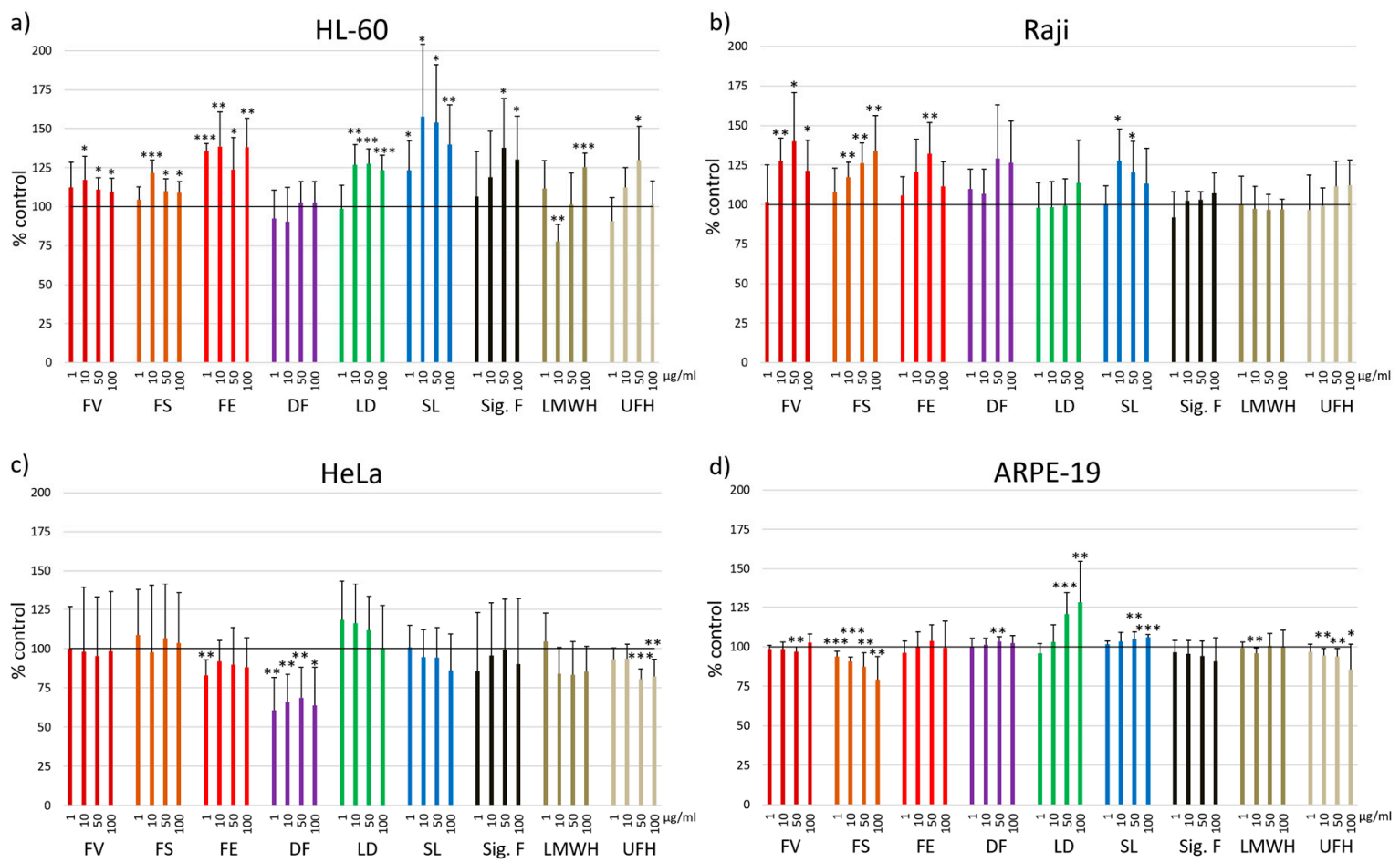

Figure 1. Cont. 

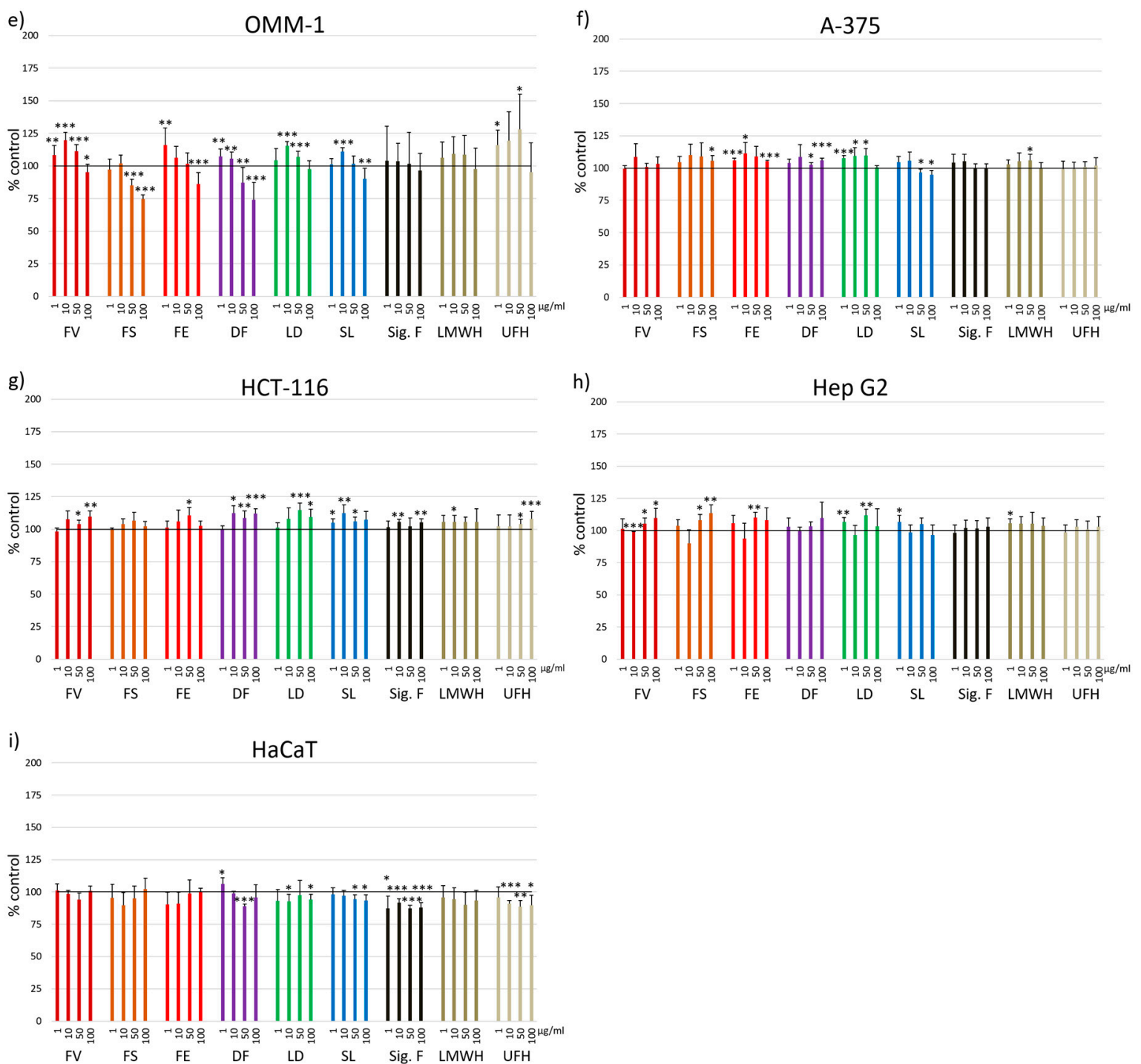

Figure 1. Cell viability was determined using MTS assay after $24 \mathrm{~h}$ incubation with 1, 10, 50 and $100 \mu \mathrm{g} / \mathrm{mL}$ fucoidan from Fucus vesiculosus (FV), Fucus serratus (FS), Fucus distichus subsp. evanescens (FE), Dictyosiphon foeniculaceus (DF), Laminaria digitata (LD) and Saccharina latissima (SL) as well as the reference substances Sigma-Aldrich fucoidan (F. vesiculosus) (Sig. F), enoxaparin (LMWH) and heparin (UFH). Nine different cell lines were tested: a) HL-60, b) Raji, c) HeLa, d) ARPE-19, e) OMM-1, f) A-375, g) HCT-116, h) Hep G2 and i) HaCaT. Values are expressed as mean and standard deviation in relation to untreated cells $(100 \%)$. Significances compared to control were determined using student's t-test * $p<0.05,{ }^{* *} p<0.01,{ }^{* * *} p<0.001, \mathrm{n} \geq 4 \times 3$.

In the non-cancerous keratinocyte cell line $\mathrm{HaCaT}$, commercial fucoidan lowered the cell viability significantly at all used concentrations $(1 \mu \mathrm{g} / \mathrm{mL} 87.1 \pm 9.6 \%, p<0.05 ; 10 \mu \mathrm{g} / \mathrm{mL} 91.8 \pm 3.0 \%, p<0.001$; $50 \mu \mathrm{g} / \mathrm{mL} 87.2 \pm 2.6 \%, p<0.001 ; 100 \mu \mathrm{g} / \mathrm{mL} 87.9 \pm 3.9 \%, p<0.001)$. The heparins had differential effects: whereas no significant change in $\mathrm{HaCaT}$ viability was detected for $\mathrm{LMWH}$, heparin showed a significant decrease at the three highest test concentrations $(10 \mu \mathrm{g} / \mathrm{mL}, 91.2 \pm 2.2 \%, p<0.001,50 \mu \mathrm{g} / \mathrm{mL}$, $88.6 \pm 4.8 \%, p<0.01,100 \mu \mathrm{g} / \mathrm{mL}, 89.7 \pm 7.7 \%, p<0.05)$.

Slight, but significant reduction of cell viability was further found for fucoidan extracts from LD $(10 \mu \mathrm{g} / \mathrm{mL} 92.8 \pm 5.1 \%, 100 \mu \mathrm{g} / \mathrm{mL}, 94.2 \pm 4.0 \%$, both $p<0.05)$ and SL $(50 \mu \mathrm{g} / \mathrm{mL} 94.3 \pm 3.4 \%, 100 \mu \mathrm{g} / \mathrm{mL}$, $93.3 \pm 4.5 \%$, both $p<0.05$ ). Notably, DF fucoidan significantly reduced the proliferation at $50 \mu \mathrm{g} / \mathrm{mL}$ $(88.9 \pm 1.7 \%, p<0.001)$. 
In addition to the incubation for $24 \mathrm{~h}$, cell viability was estimated after $72 \mathrm{~h}$ for selected cell lines (Figure 2). In general, the cell viability is mostly comparable to control. In Raji cells, no significant changes were observed compared to control except for $1 \mu \mathrm{g} / \mathrm{mL} \mathrm{FV} \mathrm{fucoidan} \mathrm{and} 1 \mu \mathrm{g} / \mathrm{mL}$ UFH $(104.5 \pm 1.9 \%, p<0.05 ; 89.9 \pm 2.1 \%, p<0.01)$. In the HeLa cell line, the cell viability was significantly decreased with $10 \mu \mathrm{g} / \mathrm{mL}$ DF fucoidan $(69.9 \pm 10.2 \%, p<0.01)$. UFH decreased viability compared to control at 50 and $100 \mu \mathrm{g} / \mathrm{mL}(82.8 \pm 10.0 \%$ and $81.4 \pm 8.6 \%$, both $p<0.05)$. SL fucoidan significantly increased viability $(10 \mu \mathrm{g} / \mathrm{mL}, 110.2 \pm 2.8 \%, p<0.01)$ as well as $1 \mu \mathrm{g} / \mathrm{mL}$ Sigma fucoidan $(114.9 \pm 8.7 \%$, $p<0.05)$. The differences of Raji and HeLa cell viability between $24 \mathrm{~h}$ and $72 \mathrm{~h}$ incubation time compared to control are minor.
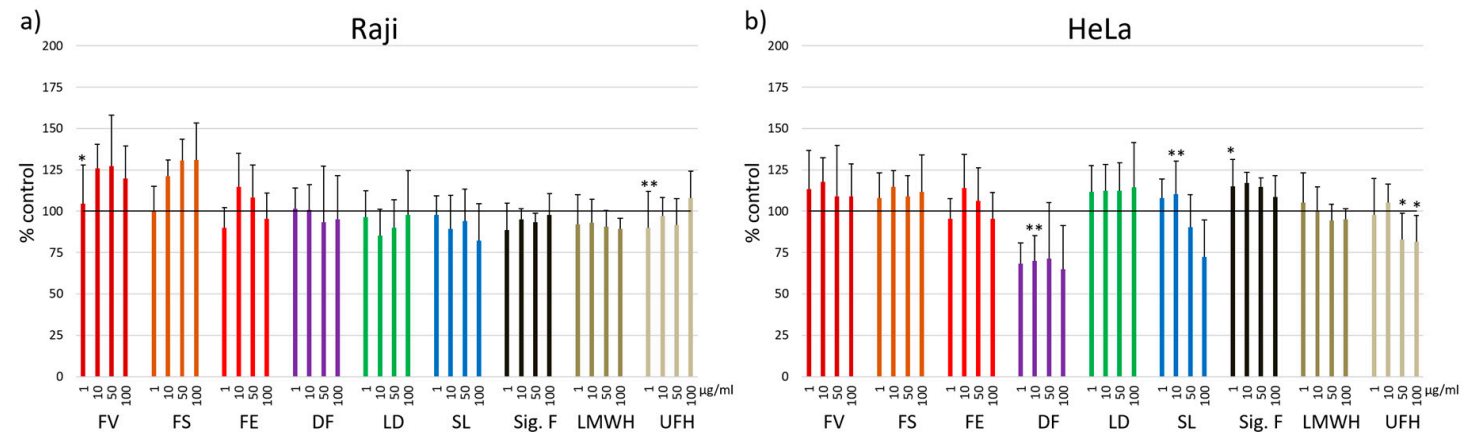

Figure 2. Cell viability was determined using MTS assay after $72 \mathrm{~h}$ incubation with 1, 10, 50 and $100 \mu \mathrm{g} / \mathrm{mL}$ fucoidan from Fucus vesiculosus (FV), Fucus serratus (FS), Fucus distichus subsp. evanescens (FE), Dictyosiphon foeniculaceus (DF), Laminaria digitata (LD) and Saccharina latissima (SL) as well as the reference substances Sigma-Aldrich fucoidan (F. vesiculosus) (Sig. F), enoxaparin (LMWH) and heparin (UFH). Two different cell lines were tested: a) Raji, b) HeLa. Values are expressed as mean and standard deviation in relation to untreated cells (100\%). Significances compared to control were determined using student's t-test ${ }^{*} p<0.05,{ }^{* *} p<0.01, \mathrm{n}=3 \times 3$.

a)

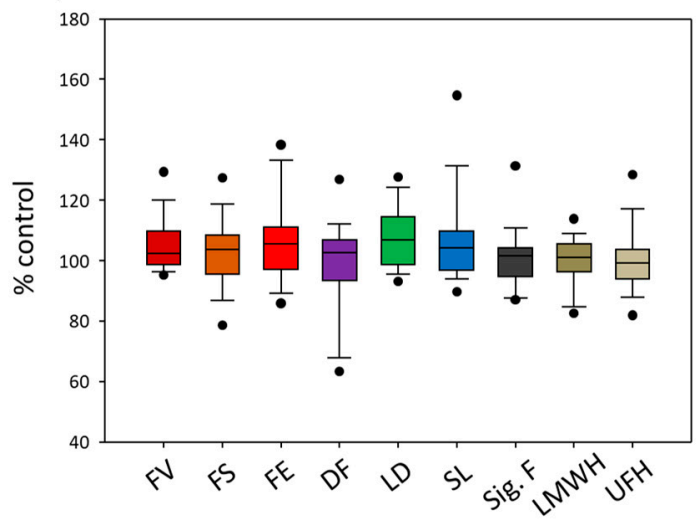

b)

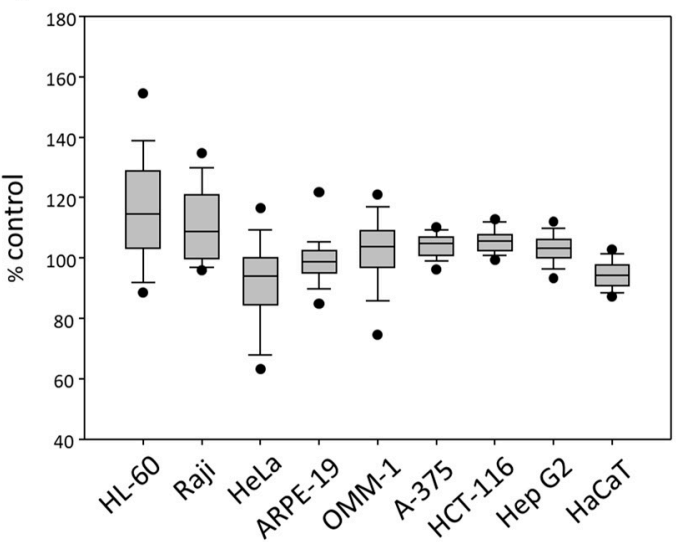

Figure 3. (a) Cell viability changes (all nine tested cell lines combined) in response to differently sourced fucoidans (i.e., from Fucus vesiculosus (FV), Fucus serratus (FS), Fucus distichus subsp. evanescens (FE), Dictyosiphon foeniculaceus (DF), Laminaria digitata (LD) and Saccharina latissima (SL)) as well as to the reference substances Sigma-Aldrich fucoidan (F. vesiculosus) (Sig. F), enoxaparin (LMWH) and heparin (UFH). (b) Cell viability changes (all nine test compounds combined, i.e., seven fucoidans, LMWH and UFH) depending on the cell line. The Whisker box plots are based on all the measured effects of each test compound (i.e., $1-100 \mu \mathrm{g} / \mathrm{mL}$ ). The boxes represent the 25 th percentile (boundary of the box closest to zero), the median (horizontal line in the box) and the 75th percentile (boundary of the box farthest from zero). Whiskers (error bars) above and below the box indicate the 95th and 5th percentiles. Outliers are shown as individual points. 
Besides the comparison of individual effects of fucoidans on the nine cell lines, we aimed to evaluate whether the differently sourced fucoidans show different effects on cell viability as well as whether the cell lines differ in their response to all fucoidans and heparins (Figure 3).

Regarding the medians (ranging from 99\% to 107\%), neither the fucoidans nor the heparins modified the cell viability (Figure 3a). The largest variability of cell viability was observed for SL (86-158\%), followed by DF (61-129\%), FS (75-134\%) and FE (83-138\%). DF and FS displayed the lowest cell viability at $61 \%$ and $75 \%$, respectively, whereas SL, LD and FV stood out by their stimulating effects on cell viability (Figure 3a).

The effect of the fucoidans and heparins on cell viability differed stronger depending on the cell line than from each used fucoidan or heparin (Figure 3b). Concerning their medians, HeLa and HaCaT $(94 \%)$ as well as HL-60 (115\%) turned out to react more sensitively than the other cell lines. Overall, the test compounds did not lower the viability of any cell line, but displayed a slightly stimulating effect for the suspension cell lines HL-60 and Raji.

To compare the effects of fucoidans on tumor and non-tumor cell lines as well as on suspension cell lines and adherent cell lines (Table 2), the respective means of cell viability after treatment with all seven fucoidans including Sigma fucoidan were calculated. Whereas the fucoidans did not significantly modify the cell viability of the non-tumor cell lines (ARPE-19 and HaCaT), they slightly, but significantly increased that of the seven tumor cell lines (HL-60, Raji, HeLa, OMM-1, A-375, HCT-116 and Hep G2) (Figure 4a). At a concentration of $1 \mu \mathrm{g} / \mathrm{mL}$, the tumor cell lines responded with $6 \%$ higher cell viability $(p<0.05)$, which further increased to 11 and $10 \%$ at 10 and $50 \mu \mathrm{g} / \mathrm{mL}(p<0.001)$. Interestingly, the increasing effect of $6 \%$ at the highest concentration $(100 \mu \mathrm{g} / \mathrm{mL})$ was not significant (Figure $4 \mathrm{a})$. Thus, the cell viability increase did not correlate with the concentration.

a)

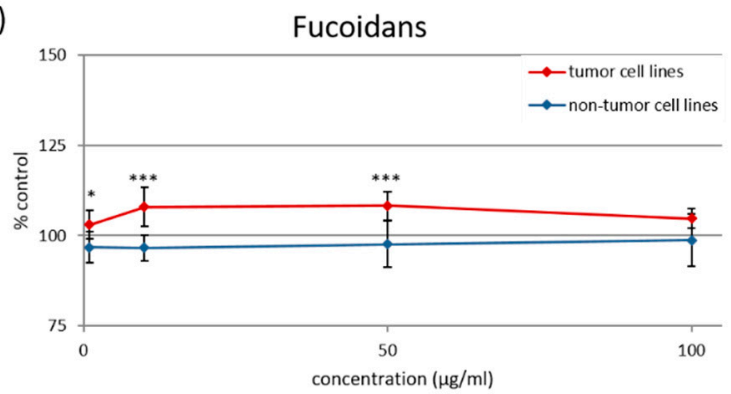

c)

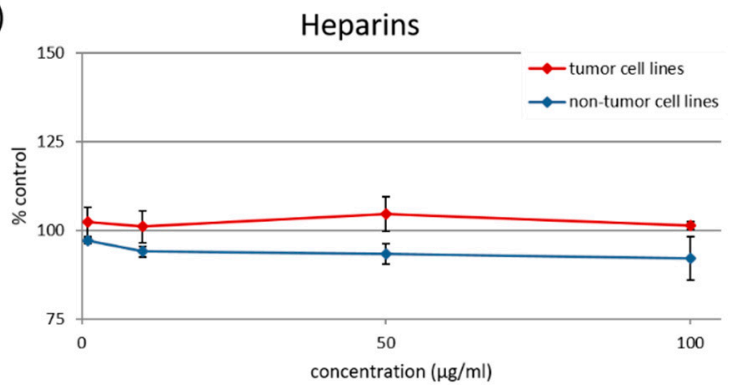

b)

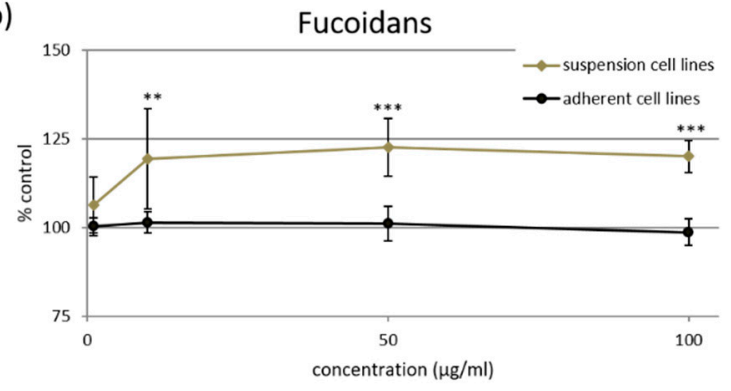

d)

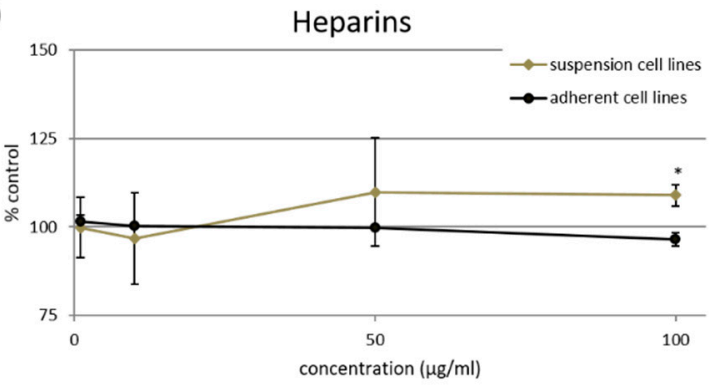

Figure 4. Cell viability effects of tested a), b) fucoidans and c), d) heparins in dependence on the type of cell line (Table 2). a) and c) show the mean cell viability of tumor and non-tumor cell lines and $\mathbf{b}$ ) and d) that of suspension and adherent cell lines. Values are expressed as mean and standard deviation in relation to untreated control (100\%). ( $\mathrm{n} \geq 4 \times 3$ ) Significances between tumor vs. non-tumor and suspension vs. adherent cell lines, respectively, were determined using student's $t$-test ${ }^{*} p<0.05$, ${ }^{* *} p<0.01,{ }^{* * *} p<0.001$.

The comparison of the suspension cell lines (HL-60 and Raji) with the adherent cell lines (HeLa, ARPE-19, OMM-1, A-375, HaCaT, HCT-116 and Hep G2) revealed a significant difference as well (Figure $4 \mathrm{~b}$ ). In contrast to any missing effect on the adherent cell lines, the fucoidans increased the cell 
viability of suspension cell lines to $119 \pm 14 \%$ at the concentrations of $10 \mu \mathrm{g} / \mathrm{mL}(p<0.01)$, to $123 \pm 8 \%$ at $50 \mu \mathrm{g} / \mathrm{mL}(p<0.001)$ and to $120 \pm 5 \%$ at $100 \mu \mathrm{g} / \mathrm{mL}(p<0.001)$.

Both comparisons (Figure $4 \mathrm{a}, \mathrm{b}$ ) did not show any reduction of the viability of the cell lines incubated with fucoidans, leading to the conclusion that fucoidans are generally neither directly cytotoxic nor impair the cell viability.

As controls, the corresponding comparisons were also performed with heparin and enoxaparin, which are known not to be cytotoxic [8] (Figure 4c,d). Although the respective differences were not significant, the results were similar to those obtained from the fucoidans. Significant was only the difference between the cell viability of the suspension and adherent cell lines incubated with $100 \mu \mathrm{g} / \mathrm{mL}$ heparins (suspension cell lines 108.9 $\pm 3.0 \%$, adherent cell lines $96.4 \pm 2.0 \%, p<0.05$ ) (Figure $4 \mathrm{~d}$ ).

In order to get indications of potential causes for the divergent reactions of the different cell lines in response to application of the different fucoidans, we performed correlation analyses between the cell viability at the highest fucoidan concentration $(100 \mu \mathrm{g} / \mathrm{mL})$ and the fucoidan characteristics protein content, total phenolic content (TPC) and fluorescence intensity (FI) increase of the glycan sulfate sensor Polymer H (unpublished data) for each cell line (Figures 5 and 6). The fluorescence intensity of Polymer $\mathrm{H}$ (a synthetic polymer based on ortho-aminomethyl-phenylboronate units, ethylammonium units and dansyl units) is specifically increased in the presence of sulfated glycans. The so-called Polymer-H assay was shown to be an useful parameter for an initial quality screening of fucoidans [31,32] (unpublished data). Concerning the protein content, which was determined by means of the N-content, free proteins are not expected to be found due to the extraction and purification process. However, protein may be tightly associated with fucoidans as shown by previous studies $[33,34]$.

a) HeLa viability vs. protein (\%)

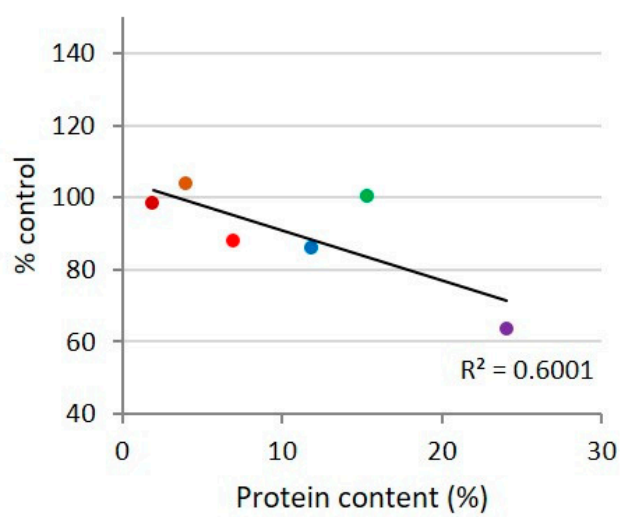

b) ARPE-19 viability vs. TPC

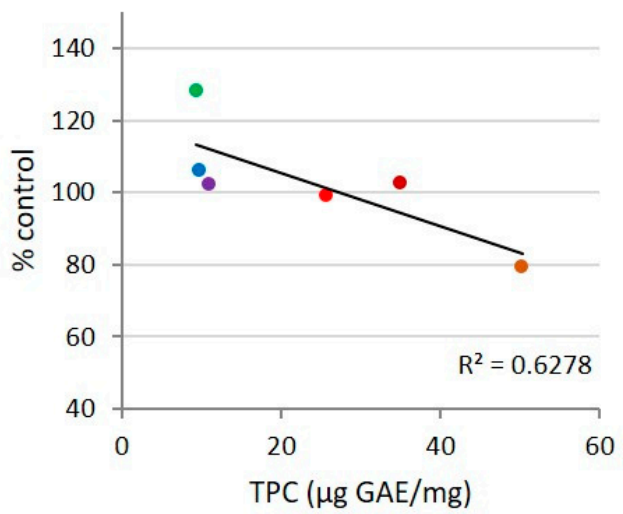

Figure 5. Correlations between viability of (a) HeLa cells and protein content of the six fucoidans and (b) ARPE-19 cells with total phenolic content (TPC). Colored dots indicate the corresponding

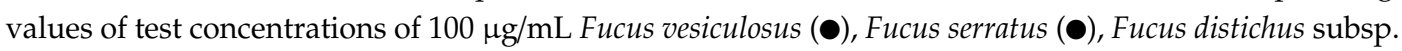
evanescens (•), Dictyosiphon foeniculaceus $(\bullet)$, Laminaria digitata $(\bullet)$ and Saccharina latissima $(\bullet)$.

For these correlation analyses, only those cell lines and fucoidan characteristics were selected wherein the effects of the six fucoidans on the cell viability differed by more than $25 \%$. There were indeed some correlations between cell viability and fucoidan characteristics (Figures 5 and 6). Negative correlations were observed between viability of HeLa cells and fucoidan protein content $\left(R^{2}=0.6001\right)$ (Figure 5a) as well as between viability of ARPE-19 cells and TPC $\left(R^{2}=0.6278\right)$ (Figure 5b). In contrast, the increase of the viability of HL-60 cells positively correlated with the FI increase of Polymer $\mathrm{H}$ $\left(R^{2}=0.7644\right)$ by the fucoidans. Additionally, HL-60 viability correlated with fucose content $\left(R^{2}=0.8994\right)$ and their DS $\left(R^{2}=0.9358\right)$ (Figure 6). 
a) $\mathrm{HL}-60$ viability vs. Polymer $\mathrm{H}$

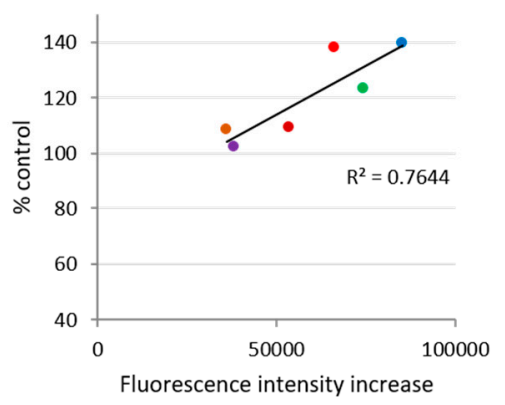

b)

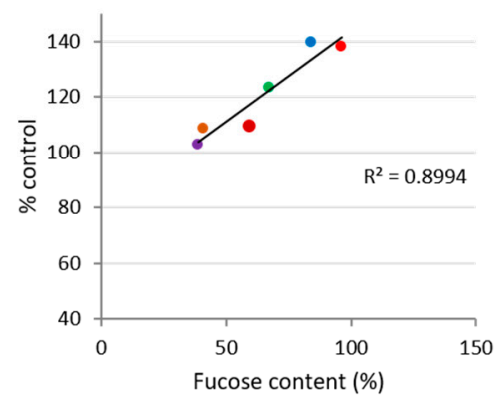

C)

HL-60 viability vs. DS

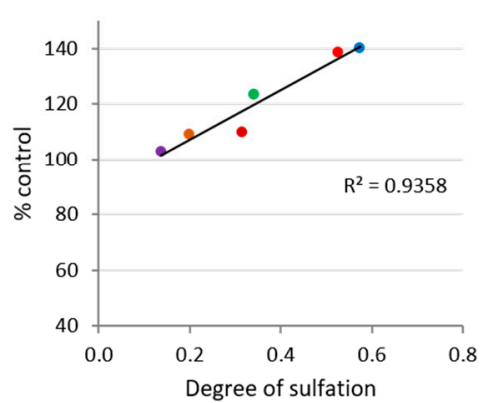

Figure 6. Correlations between viability of HL-60 cells and a) fluorescence intensity increase of Polymer-H, b) their fucose content and c) their degree of sulfation. Colored dots indicate the

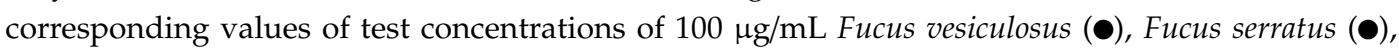
Fucus distichus subsp. evanescens $(\bullet)$, Dictyosiphon foeniculaceus $(\bullet)$, Laminaria digitata $(\bullet)$ and Saccharina latissima (•).

\section{Discussion}

Fucoidans extracted from brown algae have been described to exhibit antitumor effects [12,23,35], but also many other activities which could be beneficial for other potential applications like treatment of AMD, cosmetics and tissue regeneration $[10,16,36]$. Whereas antiproliferative effects on tumor cells are considered useful, reduction of cell viability or cytotoxic effects mostly constitute an obstacle to further development. Unfortunately, most studies investigated just one and sometimes poorly characterized fucoidan and results of various studies are not readily comparable due to different methods used for determining the parameters (e.g., cell line, assay type, concentrations). The most widely studied fucoidan is the Fucus vesiculosus fucoidan from Sigma Aldrich $[11,14,15,23,26,36-40]$, which was demonstrated to vary in structural parameters (e.g., molecular weight) and purity (e.g., TPC) depending on the batch [14]. Consequently, data from studies that do not mention catalog number and lot number are hard to interpret. Fucoidans from different algal species have rarely been directly compared in cell viability studies. Another problem is the use of high fucoidan concentrations in cell experiments $[27,37]$, which may considerably exceed those applied in vivo (e.g., therapeutic concentrations of heparins range from 5 to $15 \mu \mathrm{g} / \mathrm{mL}$ ) and/or may lead to artificial effects.

Moreover, for the cell viability analyses reported in literature, many different assays were used such as WST-1, MTT, Alamar Blue, Annexin V/PI staining, cell cycle analysis, neutral red release assay, trypan blue exclusion assay, which not always deliver similar results [20-22,24,27,28,36,37,41]. To investigate whether different fucoidans vary in their effects on cell viability as well as whether the effects differ in dependency on the cell line, we tested the cell viability using the commercially available MTS assay in a standardized assay and analysis procedure. Adequate repetitions of experiments using different cell passages are essential to interpret the data plausibly.

To come to a general statement about the influence of all tested fucoidans and the reference heparins on cell viability, we calculated the overall mean of all cell viability values after incubation with fucoidans $(n=7 \times 9 \times 4)$ and heparins $(n=2 \times 9 \times 4)$, respectively. The resulting means of $104.1 \pm 13.1 \%$ and $100.5 \pm 10.1 \%$ did not significantly differ from the control (data not shown). Additionally, in previous studies we did not find any cytotoxic effect of fucoidans measured by the release of lactate dehydrogenase (LDH) (data not shown). This leads to the conclusion that fucoidans just as heparins are non-toxic. To obtain an indication about longer incubation times, selected cell lines were treated with fucoidans and heparins for $72 \mathrm{~h}$. Here, the effects were very comparable to those after $24 \mathrm{~h}$ of incubation, i.e., similar minor stimulating or decreasing effects on cell viability, respectively. Hence, our data show no indication of long term toxicity. However, as demonstrated by the results of this study, certain fucoidans and certain cell lines, respectively, may deviate from this general conclusion. 


\subsection{Cell Line Dependency}

The results of the present study are compared with published studies investigating the effects of fucoidans on the same cell lines. As cancer cell lines are genetically unstable and often differ between laboratories, results obtained with these cell lines can be heterogeneous [42]. Therefore, caution has to be taken when comparing results of such experiments.

In the leukemia cell line HL-60 treated with fucoidans, no reduction but rather an increase of cell viability was detected (Figure 1a). In contrast, different studies described reduced cell viability of HL-60 cells treated with comparable concentrations of Sigma fucoidan (F.v.) for $48 \mathrm{~h}$ instead of $24 \mathrm{~h}$, whereby they used neutral red release assay, MTT and WST-8 proliferation assay $[38,39,43]$. Whereas the Sigma fucoidan batch used as reference in this study turned out to be very pure (bought in 2018, indicated purity $\geq 95 \%$ ), earlier studies used Sigma fucoidan of unknown purity [38], or crude extracts [39,43], which may explain the divergent results. Another reason could be the use of different assays, whereby the MTT and WST-8 proliferation assay are based on the same detection principle as MTS. Jin et al. and Atashrazm et al. additionally found a reduced cell viability of the leukemia cell line NB4, but not of K562 treated with Sigma fucoidan for 48 h [39,43], whereas Park et al. observed a reduced viability also in K562 cells [38]. After $24 \mathrm{~h}$ Jin et al. did not see a significant reduction in cell viability [39], which is comparable to our results. Accordingly, one cause for these different results could also be the different incubation times being associated e.g., with different availability of nutrients.

The influence of fucoidan purity on cell viability has previously been demonstrated by experiments with the Burkitt lymphoma cell line Raji: Crude Sigma fucoidan exerted an antiproliferative effect on Raji cells, whereas the fraction purified by ion exchange chromatography did not show such an effect [14]. Similarly, crude Sigma fucoidan had an antiproliferative effect, but fractions treated with $\mathrm{H}_{2} \mathrm{O}_{2}$ did not [15]. Moreover, Schneider et al. additionally tested fucoidan from SL, which was extracted with the same method as used in the current study [14]. Like the SL tested in the present study, SL fucoidan from the previous study contained considerably less coextracted phenolic compounds than the fucoidans from Fucus sp. and did not influence the proliferation [14].

Saravana et al. and Jiang et al. tested fucoidan from Saccharina japonica and Ascophyllum nodosum on the HeLa cell line which showed no significant effect on cell viability [20,21], whereas Sigma fucoidan (purity $\geq 95 \%$ ) and abalone glycosidase-digested fucoidan from Cladosiphon novae-caledoniae inhibited the cell proliferation $[20,35]$. The effects on cell viability were thus dependent on the algae species, which fits to our results with HeLa, where DF fucoidan but none of the other test compounds displayed an antiproliferative effect. Regarding the discrepant findings by Saravana et al. on Sigma fucoidan, it has to be considered that they tested $1 \mathrm{mg} / \mathrm{mL}$, whereas we examined 10-1000 fold lower concentrations [20].

In line with our data on ARPE-19 cells, Dithmer et al. and Li et al. observed no toxic effect of $100 \mu \mathrm{g} / \mathrm{mL}$ Sigma fucoidan on ARPE-19 cells [18,44]. Proliferative effects on other epithelial cells like endothelial progenitor cells (EPC) and human umbilical vein endothelial cells (HUVEC) were described for $100 \mu \mathrm{g} / \mathrm{mL}$ low-molecular-weight fucoidan from Ascophyllum nodosum [45]. In EPC a concentration-dependent increase of cell viability was detected [45] which fits with the effects of LD fucoidan in our study.

In the OMM-1 cell line, neither pure Sigma fucoidan (Figure 1) nor crude Sigma fucoidan had any effect on proliferation [36], whereas OMM2.5 and Mel270, two other uveal melanoma cell lines, reacted by activating and inhibiting proliferation, respectively [36]. It should additionally be mentioned, that OMM-1 was one of the cell lines, where we observed both proliferation stimulating (FV, FE, LD, SL) and inhibiting effects depending on the algal species and the concentration of the various fucoidans (FV, FS, FE, DF, SL).

To our knowledge, the present study is the first one testing fucoidans on cell viability of A-375 skin melanoma cells, but there are some studies using B16 and RPMI-7951 skin melanoma cells. Similar to our results, Wang et al. found no effect on the cell viability of B16 cells treated with $100 \mu \mathrm{g} / \mathrm{mL}$ Sigma fucoidan (of undefined purity) for $48 \mathrm{~h}$ using the cell counting kit-8 (CCK8). This was confirmed 
by Ale et al. 2011, who tested crude Sigma fucoidan using MTT assay. However, 6-10 times higher concentrations reduced the B16 viability in both studies [46,47]. Vishchuk et al. tested fractions of $200 \mu \mathrm{g} / \mathrm{mL}$ fucoidans from S. cichorioides, F. evanescens and U. pinnatifida on the skin melanoma cell line RPMI-7951 and showed a slight reduction of cell viability after $24 \mathrm{~h}$ using MTS assay, which could be due to the higher concentration [30]. Furthermore, the cell viability of RPMI-7951 cells after $72 \mathrm{~h}$ was reduced, which could be explained by the extended incubation time [30].

A recent study of Park et al. reported the time- and concentration-dependent effects of crude Sigma fucoidan (Source: F.v.) on HCT-116 cells [48]. The concentration of $100 \mu \mathrm{g} / \mathrm{mL}$ fucoidan significantly reduced the viability by about $15-20 \%$ after $24 \mathrm{~h}$ incubation and about $50 \%$ after $48 \mathrm{~h}$ [48]. In the present study, neither the pure Sigma fucoidan nor any other of the test compounds reduced the viability of the HCT-116 cells, but on the contrary slightly increased cell viability.

Two studies on hepatocellular carcinoma cell line Hep G2 further underline the importance of concentration and purity of fucoidan regarding cellular effects [37,49]. In the study of Roshan et al. (2014), incubation with high concentrations (200-6000 $\mu \mathrm{g} / \mathrm{mL})$ of Sigma fucoidan for $24 \mathrm{~h}$ concentration-dependently reduced the cell proliferation and viability (by about $20 \%$ at $200 \mu \mathrm{g} / \mathrm{mL}$ ) [37]. Zhurishkina et al. investigated both crude fucoidan from F. vesiculosus and two purified fractions obtained by ion-exchange chromatography [49]. In accordance with our results, treatment of Hep G2 cells with $120 \mu \mathrm{g} / \mathrm{mL}$ of the compounds for $24 \mathrm{~h}$ did not modify the cell viability and proliferation [49]. The same was found for the two purified fractions after incubation for 48 and $72 \mathrm{~h}$, whereas the crude fucoidan reduced the cell viability [49].

Regarding HaCaT keratinocytes, Ryu et al. reported that fucoidan (unknown source) did not affect the cell viability up to $50 \mu \mathrm{g} / \mathrm{mL}$, whereas $100 \mu \mathrm{g} / \mathrm{mL}$ fucoidan reduced it by about $10 \%$, which corresponds to our findings on Sigma fucoidan [50]. A purified fraction from fucoidan extracted from Turbinaria conoides revealed, however, no cell viability reducing effect up to $1000 \mu \mathrm{g} / \mathrm{mL}$ [51].

Overall, the literature confirms that different cell lines react differently to fucoidans regarding cell viability (Figure 3b) and the influence of different fucoidans on cell viability varies as well (Figure 3a). Among the tested cell lines, HL-60 and Hela turned out as the most sensitive ones, whereby the viability of HL-60 was rather increased, whereas that of Hela was slightly reduced.

\subsection{Comparison of Non-Tumor and Tumor Cell Lines}

The viability of the two non-tumor cell lines ARPE-19 and HaCaT turned out to be not modified by the tested fucoidans (Figures $3 \mathrm{~b}$ and $4 \mathrm{a}$ ). This is consistent with most of the literatureconcerning the effects of fucoidans on non-tumor cells $[11,18,21,27,52-55]$. No influence on the cell viability was reported for ARPE-19, WI-38 (human lung fibroblasts), Vero (African green monkey kidney), L929 (mouse fibroblasts), FHC (human normal colon epithelium), and RPE cells [11,18,52,54,55]. In human skin fibroblasts (HSF), a reduction in cell viability was only observed at a concentration of $5 \mathrm{mg} / \mathrm{mL}$ [53]. Gazha et al. reported that as much as $500 \mathrm{mg} / \mathrm{mL}$ fucoidan from L. japonica, L. cichorioides and $F$. evanescens, respectively, were required to induce apoptosis on human peripheral blood lymphocytes (PBL) [27].

In contrast to the non-tumor cell lines, the fucoidans slightly increased the viability of the seven tumor cell lines (Figures $3 b$ and $4 a$ ). However, this overall result was actually due to the stimulation of the proliferation of HL-60 and Raji cells. Most studies describe that the cell viability in tumor cell lines was decreased by fucoidans due to different mechanisms [11,20,23,24,28,37,41,51,54,55]. For example, antiapoptotic Bcl-2 was decreased by fucoidans $[11,24,55]$. Another example is cell cycle arrest such as $G_{0}$ or $S_{u b G}$ or $G_{1}$ phase arrest $[24,28,51]$. Roshan et al. detected an increased generation of intracellular reactive oxygen species (ROS), which could be related with apoptosis induction [37]. The discrepant results between this study and the literature may be due to used cell line, fucoidan, purity of the fucoidan [11], concentration [20,23,24,37,41,51,55] and incubation time [11,20,23,28,51,54,55]. The relevance of the antiproliferative effects of fucoidans on tumor cells is currently unclear, since they exhibit numerous other effects contributing to their antitumor and antimetastatic activity (e.g., 
inhibition of angiogenesis, tumor cell migration, adhesion to extracellular matrix components and extracellular matrix degradation, antagonization of chemokines and adhesion molecules, stimulation of natural killer cells).

\subsection{Comparison of Suspension and Adherent Cell Lines}

In total, we detected a stimulating effect of the fucoidans on the viability of the two suspension cell lines HL-60 and Raji, whereas the mean viability of the seven adherent cell lines was not modified (Figures $3 b$ and $4 b$ ). There are numerous studies investigating the influence of fucoidans on the viability of blood cancer cells including K562, NB4, THP-1, HS-Sultan, BCBL-1, TY-1, HL-60, U937 [23,25,38-40]. All of these studies reported either no or a reducing effect on the cell viability. In a previous study on Raji cells, fucoidan from S. latissima and purified Sigma fucoidan stimulated the cell proliferation measured using a BrdU-based proliferation ELISA, whereas the Sigma fucoidan (other batch than used in the present study) reduced the proliferation [13]. The stimulating effect was stronger after $48 \mathrm{~h}$ incubation than after $24 \mathrm{~h}$ and $72 \mathrm{~h}$, however only significant for $150 \mu \mathrm{g} / \mathrm{mL}$ of the Sigma fucoidan after $48 \mathrm{~h}$. Therefore, the question arises whether the increased cell viability measured with the MTS assay really results from increased proliferation or rather represents increased metabolic activity due to cell activation. This needs further investigations, whereby the best answer would be obtained by in vivo experiments on the antitumor activity of fucoidans in leukemia and lymphoma. It was previously described, that fucoidan fed mice developed lower tumor volume and tumor weight than the control mice after injection of blood cancer cells $[43,56]$.

Regarding the adherent cells, the detection of any proliferation stimulating effect is impeded by the fact that further proliferation of confluent cells is restricted because of the limited growth area.

\subsection{Effect of Heparins on Cell Viability}

According to the overall mean of the cell viability, the heparins (UFH, LMWH) showed no significant effects $(100.5 \pm 10.1 \%)$. Similar to the fucoidans, there were certain differences depending on the cell line, but even significant effects amounted to less than $22 \%$.

Heparin and enoxaparin, respectively, showed no effect on the proliferation on endothelial cells [57], human pulmonary epithelial cells A-549 and primary human osteoblasts [58,59]. This is comprehensible, as heparin is an endogenous compound of the human body. Further, heparins are well-known to exhibit antitumor and antimetastatic activity in vivo, but this is mainly due to other mechanisms than cytotoxic or antiproliferative effects [8]. Accordingly, heparin and enoxaparin turned out to have no influence on the viability of tumor cell lines [60,61]. However, in contrast to these findings, the viability of the human choriocarcinoma cell line JEG-3 was described to be stimulated [62], whereas the viability of three of four SCC (squamous cell carcinoma) cell lines after treatment with unfractionated heparin for 12, 24 and $48 \mathrm{~h}$ was reduced [63]. Such discrepant results underline that tumor cells may largely differ from each other and thus also in their reactions to any compounds. Heparan sulfate is described as a proliferation modulating substance and plays an important role in cancer diseases $[64,65]$. Saad et al. showed a decrease in cell viability of hepatocellular cell lines Hep G2 and HuH7 incubated with a mutant glypican 3 (heparan sulfate proteoglycan) without its GPI anchor [66]. On the other hand, it stimulated the growth of exponentially growing hepatocytes [67]. In general, heparan sulfate proteoglycans can act as positive or negative modulators of cell proliferation [67]. This depends on the cell type, the type of heparan sulfate and its interaction with for instance growth factors [66].

\subsection{Correlation Analysis of Cell Viability and Characteristics of the Fucoidans}

Analysis of the correlation between the cell viability and various characteristics of the six different fucoidans suggest that highly pure fucoidans do not impair the cell viability. The viability of HeLa cells negatively correlated with the protein content of the fucoidans (Figures $1 \mathrm{c}$ and $5 \mathrm{a}$ ) and that of ARPE-19 negatively correlated with the TPC (Figures $1 \mathrm{~d}$ and $5 \mathrm{~b}$ ). The latter is supported by the data 
for Sigma fucoidan having no antiproliferative effect (Figure 1g) as well as a low total phenolic content (data not shown, manuscript submitted). Some articles demonstrated that co-extracted compounds e.g., polyphenols are responsible for antiproliferative effects $[14,15,68]$ and polyphenols extracted from brown algae were reported to exhibit pronounced antiproliferative effects [14,69]. Moreover, the viability of HL-60 cells positively correlated with the FI increase of Polymer-H, the DS and the fucose content of the fucoidans, whereby the viability was stimulated compared to the control. Polymer-H can be used as quality marker for fucoidans; its FI increase by fucoidans is related to their purity and biological activity ([32] manuscript submitted). The higher the fucose content and the DS of a crude fucoidan, the lower is its content of co-extracted compounds such as polyphenols, laminarin and alginic acid. Thus, a higher fucoidan purity was associated with an increase of viability of HL-60 cells. In general, well defined and highly purified fucoidans are an essential prerequisite for the development of medical applications.

Depending on the algae species the purity of the extracted crude fucoidans was shown to differ (manuscript submitted) and this characteristic turned out as the most important one for changes of the viability of the used cell lines. Due to the overall only small effects of the fucoidans on the cell viability, its impact was only observed in those three cell lines with the largest fucoidan-dependent variability. This may be also the reason for missing correlations between the cell viability and other parameters such as the molecular weight (data not shown), although that is generally considered an important parameter for the biological activities of fucoidans [15,70,71].

\section{Materials and Methods}

\subsection{Algal Material and Extraction Method}

The algal material was kindly provided by the company Coastal Research \& Management GmbH (Kiel, Germany). The used algae species for extraction, their harvest date and place are shown in Table 1. The fucoidans were extracted as previously described [34] and characterized (unpublished data). At first, Soxhlet extraction with $99 \%(v / v)$ ethanol was applied for defatting of the pulverized algal material. Then, the algal material was extracted using aqueous $2 \%$ calcium chloride for $2 \mathrm{~h}$ at $85^{\circ} \mathrm{C}$ under reflux conditions. The supernatants of the raw extracts were concentrated by evaporation and precipitated with ice-cold ethanol in a final concentration of $60 \%$ at $4{ }^{\circ} \mathrm{C}$. The precipitate was centrifuged, dissolved in demineralized water, dialyzed and lyophilized.

Table 1. Algal species, their harvest dates and sites.

\begin{tabular}{cccc}
\hline Fucoidan & Algae Species & Harvest Date & Origin \\
\hline SL & Saccharina latissima & July 2016 & North Atlantic Ocean \\
DF & Dictyosiphon foeniculaceus & May 2017 & Baltic Sea \\
LD & Laminaria digitata & June 2017 & North Atlantic Ocean \\
FV & Fucus vesiculosus & July 2017 & Baltic Sea \\
FS & Fucus serratus & July 2017 & Baltic Sea \\
FE & Fucus distichus subsp. evanescens & July 2017 & Baltic Sea \\
\hline
\end{tabular}

\subsection{Reference Substances}

As reference compounds fucoidan (Fucus vesiculosus) from Sigma Aldrich (Deisenhofen, Germany, purity $\geq 95 \%$, Cat. No. F8190, Lot \# SLBT5471), heparin (Cat. No. Y0001282) and enoxaparin (Cat. No. E0180000) from EDQM were purchased and solved in Ampuwa water (Fresenius Kabi, Schweinfurt, Germany).

\subsection{Cell Culture}

The human cell lines Raji (Burkitt lymphoma, ACC 319), HL-60 (acute promyelocytic leukemia, ACC 3), HCT-116 (colon carcinoma, ACC 581) and Hep G2 (hepatocellular carcinoma, ACC 180) were 
purchased from the German Collection of Microorganisms and Cell Cultures (DSMZ, Braunschweig, Germany). The HeLa cell line (cervical adenocarninoma) was a kind gift of Prof. Dr. Clement (Institute of Pharmacy, Kiel University, Germany). ARPE-19 cells (immortal human retinal epithelium) were bought from ATCC (CRL-2302TM, Manassas, VA, USA). The OMM-1 cell line (uveal melanoma, sub-cutaneous metastasis) was a kind gift of Dr. Sarah Coupland (North-West Cancer Research Institute, University of Liverpool, UK). The human malignant melanoma cell line A375 (skin melanoma) and the immortalized $\mathrm{HaCaT}$ cell line (keratinocytes) were purchased from Cell Line Service (Eppelheim, Germany).The characteristics of the used cell lines are shown in Table 2.

Table 2. Characteristics of the used cell line.

\begin{tabular}{cccc}
\hline Cell Line & Cell Type & Suspension/Adherent & Tumor/Non-Tumor \\
\hline HL-60 & Acute promyelocytic leukemia & suspension & tumor \\
Raji & Burkitt lymphoma & suspension & tumor \\
HeLa & Cervical adenocarninoma & adherent & tumor \\
ARPE-19 & Human retinal epithelium & adherent & non-tumor \\
OMM-1 & Uveal melanoma & adherent & tumor \\
A-375 & Skin melanoma & adherent & tumor \\
HCT-116 & Colon carcinoma & adherent & tumor \\
Hep G2 & Hepatocellular carcinoma & adherent & tumor \\
HaCaT & Keratinocytes & adherent & non-tumor \\
\hline
\end{tabular}

Raji, HL-60 and HeLa cell lines were cultivated in RPMI-1640 (Merck, Darmstadt, Germany, Cat. No. FG 1215, 11.11 mM D-Glucose) with 10\% heat inactivated fetal bovine serum (FBS). The ARPE-19 cell line was cultivated in DMEM (Merck, Cat. No. FG0445, $25 \mathrm{mM}$ D-glucose) with 10\% FBS and 1\% penicillin/streptomycin and 1\% non-essential amino acids. OMM-1 cells were cultivated in RPMI-1640 (Merck, Cat. No. FG 1215, $11.11 \mathrm{mM}$ D-glucose) with 10\% FBS and 1\% penicillin/streptomycin. HaCaT and Hep G2 cell lines were cultivated in Gibco RPMI-1640 (Thermo Fisher, Bremen, Germany, Cat. No $21875034,11.11 \mathrm{mM}$ D-glucose) medium supplemented with 10\% FBS and 1\% penicillin/streptomycin. The A-375 and HCT-116 cell line were cultivated in DMEM (Thermo Fisher, Cat. No. 11995065, 25 mM D-glucose) after adding 10\% FBS and 1\% penicillin/streptomycin. All cell lines were incubated in a humidified incubator at $37^{\circ} \mathrm{C}$ and $5 \% \mathrm{CO}_{2}$.

\subsection{MTS Assay}

The CellTiter $96^{\circledR}$ AQueous One Solution Cell Proliferation Assay (Promega, Mannheim, Germany) was used to determine cell viability. The assay was performed in 96-well microplates in phenol red-free medium (HL-60, HeLa, Raji and OMM-1: RPMI 1640: Cat. No. F 1275, 11.11 mM D-glucose; ARPE-19: HyClone DMEM (GE Healthcare, Hamburg, Germany, Cat. No. SH30284.01, 25 mM D-glucose)). For HL-60, HeLa and Raji cells 1X Gibco GlutaMAX ${ }^{\mathrm{TM}}-\mathrm{I}$ (Life Technologies, Carlsbad, CA, USA, 35050-038) was added. The medium for ARPE-19 and OMM-1 was supplemented as described above in cell culture. For OMM-1 cells 2 mM L-glutamine (Merck, Cat. No. K0282) was added. For Hep G2, HaCaT, A-375 and HCT-116 cell lines the cell viability assay was also performed using Gibco RPMI 1640 medium as described above for cell culture. Extracts in medium were filtered through a $0.2 \mu \mathrm{m}$ filter before treatment (Sarstedt, Nümbrecht, Germany, Cat. No. 83.1826.001). The Raji (10.000 cells/100 $\mu \mathrm{L}$ ) and HL-60 (15.000 cells/100 $\mu \mathrm{L})$ cells were seeded and treated with fucoidan extracts on the same day. ARPE-19 cells (10.000 cells/100 $\mu \mathrm{L})$ were seeded and treated at $100 \%$ confluence. OMM- 1 cells were treated at $80 \%$ confluence. HeLa (3000 cells $/ 100 \mu \mathrm{L}$ ), Hep G2, HaCaT, A-375 and HCT-116 cells (each 10.000 cells $/ 100 \mu \mathrm{L}$ ) were seeded the day before treatment with fucoidan.

Cells were treated with the six different fucoidans as well as with the reference compounds (Sigma fucoidan, enoxaparin and heparin) in four different concentrations $(1,10,50$ and $100 \mu \mathrm{g} / \mathrm{mL})$ for $24 \mathrm{~h}$. As control, cells treated with $100 \mu \mathrm{L}$ medium were used. After the incubation time $20 \mu \mathrm{L}$ of the 
MTS solution were added to each well and incubated for $1 \mathrm{~h}$ at $37^{\circ} \mathrm{C}, 5 \% \mathrm{CO}_{2}$. The absorbance was measured at $490 \mathrm{~nm}$.

\subsection{Statistical Analysis}

Each experiment was performed in triplicates at least four times. Data of the experiments were analyzed statistically in Microsoft Excel using the mean, standard deviation and Student's $t$-test. A Student's $t$-test with $p<0.05$ was considered as significant. All bars represent mean and standard deviation.

\section{Conclusions}

Due to the heterogeneous and partly conflicting data in the literature, the aim of the present study was to investigate the effects of different fucoidans on cell viability and to compare them depending on cell line and type (suspension/adherent, tumor/non-tumor cell lines). For this, six fucoidans extracted from different brown algal species (Fucus vesiculosus, F. serratus, F. distichus subsp. evanescens, Dictyosiphon foeniculaceus, Laminaria digitata, and Saccharina latissima) as well as three reference compounds (Sigma fucoidan, heparin, enoxaparin) were tested on nine different human cell lines (HL-60, Raji, HeLa, ARPE-19, OMM-1, A-375, HCT-116, Hep G2, and HaCaT). The cell viability was determined by the commercially available MTS assay according to a standardized test and analysis protocol for comparability of the results. After $24 \mathrm{~h}$ incubation of the cells with the fucoidans $(1-100 \mu \mathrm{g} / \mathrm{mL})$, the overall mean of the cell viability amounted to $104.1 \pm 13.1 \%$ and was quite similar to that of the heparins $(100.5 \pm 10.1 \%)$, which are known to exhibit no antiproliferative effects. Although some individual cell viability values were significantly reduced compared to the control (at most of HeLa by DF, i.e., $39 \%$ reduction), no consistent antiproliferative effect was found for any fucoidan. The cell viability medians of the different fucoidans ranged from $99 \%$ to $107 \%$, whereby the largest cell line- and concentration-dependent variability was observed for SL (86-158\%) and DF (61\%-129\%). As indicated by the medians of the different cell lines ranging from $94 \%$ (HeLa and $\mathrm{HaCaT}$ ) to $115 \%$ (HL-60), the cell lines differently reacted to fucoidans. Whereas cell viability of the adherent cell lines was not influenced by the fucoidans, that of the suspension cell lines (HL-60, Raji) was significantly increased. In contrast to the non-tumor cell lines (ARPE-19, HaCaT), the viability of the tumor cell lines was also slightly increased, but this was mainly due to the increased viability of HL-60 and Raji cells. Analyses on the role of the various analytical fucoidan characteristics for their marginally different cellular effects revealed that the effect on the cell viability is primarily dependent on the purity of the fucoidans including co-extracted compounds. The cell viability of HeLa and ARPE-19 cells negatively correlated with protein content and TPC, respectively, whereas that of HL-60 cells positively correlated with FI increase of Polymer $\mathrm{H}$, fucose content and DS.

In summary, none of the tested fucoidans turned out to impair the cell viability, when tested at concentrations typical for systemic therapeutic applications. This makes them suitable for further investigations concerning many different applications. Despite the lack of antiproliferative effects on tumor cells, fucoidans still are of interest as potential antitumor agents due to numerous other antitumor mechanisms (e.g., inhibition of angiogenesis, tumor cell migration, tumor cell adhesion).

Author Contributions: Conceptualization, A.K., D.T., S.A.; Methodology, A.K., K.S.B., M.B., P.D., S.A.; Validation, K.S.B., P.D.; Formal Analysis, K.S.B., P.D.; Investigation, K.S.B., M.B., P.D.; Resources, A.K., D.T., J.R., S.A.; Data Curation, A.K., S.A.; Writing-Original Draft Preparation, K.S.B., P.D.; Writing-Review \& Editing, A.K., K.S.B., M.B., D.T., S.A., P.D.; Visualization, K.S.B., P.D.; Supervision, A.K., D.T., J.R., S.A.

Funding: This research was funded by InterReg-Deutschland-Denmark. A.K. was funded by the Herrmann -Wacker-Foundation.

Acknowledgments: This study is part of the FucoSan-Health from the Sea-Project and is supported by EU InterReg-Deutschland-Denmark and the European Fond of Regional Development. We thank Jana Heumann for performing cancer cell line assays for A-375, Hep G2, HaCaT and HCT-116 and Coastal Research \& Management, Kiel, for providing the algal material. 
Conflicts of Interest: The authors declare no conflict of interest.

\section{References}

1. Timp, J.F.; Braekkan, S.K.; Versteeg, H.H.; Cannegieter, S.C. Epidemiology of cancer-associated venous thrombosis. Blood 2013, 122, 1712-1723. [CrossRef] [PubMed]

2. Van Es, N.; Bleker, S.M.; Wilts, I.T.; Porreca, E.; Di Nisio, M. Prevention and treatment of venous thromboembolism in patients with cancer: Focus on drug therapy. Drugs 2016, 76, 331-341. [CrossRef] [PubMed]

3. NCCN. Clinical Practice Guidelines in Oncology VTE Version II; National Comprehensive Cancer Network (NCCN) Fort: Washington, PA, USA, 2017.

4. Akl, E.A.; Gunukula, S.; Barba, M.; Yosuico, V.E.D.; van Doormaal, F.F.; Kuipers, S.; Middeldorp, S.; Dickinson, H.O.; Bryant, A.; Schünemann, H. Parenteral anticoagulation in patients with cancer who have no therapeutic or prophylactic indication for anticoagulation. Cochrane Database Syst. Rev. 2011, CD006652. [CrossRef]

5. Akl, E.A.; Kahale, L.A.; Ballout, R.A.; Barba, M.; Yosuico, V.E.D.; van Doormaal, F.F.; Middeldorp, S.; Bryant, A.; Schünemann, H. Parenteral anticoagulation in ambulatory patients with cancer. Cochrane Database Syst. Rev. 2014, 9, CD006652.

6. Noble, S. Heparins and cancer survival: Where do we stand? Thromb. Res. 2014, 133, S133-S138. [CrossRef]

7. Zhang, N.; Lou, W.; Ji, F.; Qiu, L.; Tsang, B.K.; Di, W. Low molecular weight heparin and cancer survival: Clinical trials and experimental mechanisms. J. Cancer Res. Clin. Oncol. 2016, 142, 1807-1816. [CrossRef]

8. Alban, S. Pharmacological strategies for inhibition of thrombin activity. Curr. Pharm. Des. 2008, 14, 1152-1175. [CrossRef] [PubMed]

9. Fitton, J.; Dell'Acqua, G.; Gardiner, V.-A.; Karpiniec, S.; Stringer, D.; Davis, E. Topical benefits of two fucoidan-rich extracts from marine macroalgae. Cosmetics 2015, 2, 66-81. [CrossRef]

10. Fitton, J.H.; Stringer, D.N.; Karpiniec, S.S. Therapies from Fucoidan: An Update. Mar. Drugs 2015, 13, 5920-5946. [CrossRef]

11. Xue, M.; Ge, Y.; Zhang, J.; Wang, Q.; Hou, L.; Liu, Y.; Sun, L.; Li, Q. Anticancer properties and mechanisms of fucoidan on mouse breast cancer In Vitro and In Vivo. PLoS ONE 2012, 7, e43483. [CrossRef]

12. Van Weelden, G.; Bobiński, M.; Okła, K.; van Weelden, W.J.; Romano, A.; Pijnenborg, J.M.A. Fucoidan structure and activity in relation to anti-cancer mechanisms. Mar. Drugs 2019, 17, 32. [CrossRef]

13. Schoenfeld, A.-K.; Lahrsen, E.; Alban, S. Regulation of complement and contact system activation via C1 inhibitor potentiation and factor XIIa activity modulation by sulfated glycans-structure-activity relationships. PLoS ONE 2016, 11, e0165493. [CrossRef]

14. Schneider, T.; Ehrig, K.; Liewert, I.; Alban, S. Interference with the CXCL12/CXCR4 axis as potential antitumor strategy: Superiority of a sulfated galactofucan from the brown alga Saccharina latissima and fucoidan over heparins. Glycobiology 2015, 25, 812-824. [CrossRef]

15. Lahrsen, E.; Liewert, I.; Alban, S. Gradual degradation of fucoidan from Fucus vesiculosus and its effect on structure, antioxidant and antiproliferative activities. Carbohydr. Polym. 2018, 192, 208-216. [CrossRef]

16. Wang, F.; Schmidt, H.; Pavleska, D.; Wermann, T.; Seekamp, A.; Fuchs, S. Crude fucoidan extracts impair angiogenesis in models relevant for bone regeneration and osteosarcoma via reduction of VEGF and SDF-1. Mar. Drugs 2017, 15, 186. [CrossRef]

17. Purnama, A.; Aid-Launais, R.; Haddad, O.; Maire, M.; Mantovani, D.; Letourneur, D.; Hlawaty, H.; Le Visage, C. Fucoidan in a 3D scaffold interacts with vascular endothelial growth factor and promotes neovascularization in mice. Drug Deliv. Transl. Res. 2015, 5, 187-197. [CrossRef]

18. Dithmer, M.; Fuchs, S.; Shi, Y.; Schmidt, H.; Richert, E.; Roider, J.; Klettner, A. Fucoidan reduces secretion and expression of vascular endothelial growth factor in the retinal pigment epithelium and reduces angiogenesis in vitro. PLoS ONE 2014, 9, e89150. [CrossRef]

19. Dörschmann, P.; Bittkau, K.S.; Neupane, S.; Roider, J.; Alban, S.; Klettner, A. Effects of fucoidans from five different brown algae on oxidative stress and VEGF interference in ocular cells. Mar. Drugs 2019, 17, 258. [CrossRef] 
20. Saravana, P.S.; Tilahun, A.; Gerenew, C.; Tri, V.D.; Kim, N.H.; Kim, G.-D.; Woo, H.-C.; Chun, B.-S. Subcritical water extraction of fucoidan from Saccharina japonica: Optimization, characterization and biological studies. J. Appl. Phycol. 2018, 30, 579-590. [CrossRef]

21. Jiang, Z.; Okimura, T.; Yokose, T.; Yamasaki, Y.; Yamaguchi, K.; Oda, T. Effects of sulfated fucan, ascophyllan, from the brown Alga Ascophyllum nodosum on various cell lines: A comparative study on ascophyllan and fucoidan. J. Biosci. Bioeng. 2010, 110, 113-117. [CrossRef]

22. Chen, H.-Y.; Huang, T.-C.; Lin, L.-C.; Shieh, T.-M.; Wu, C.-H.; Wang, K.-L.; Hong, Y.-H.; Hsia, S.-M. Fucoidan Inhibits the Proliferation of Leiomyoma Cells and Decreases Extracellular Matrix-Associated Protein Expression. Cell. Physiol. Biochem. 2018, 49, 1970-1986. [CrossRef]

23. Aisa, Y.; Miyakawa, Y.; Nakazato, T.; Shibata, H.; Saito, K.; Ikeda, Y.; Kizaki, M. Fucoidan induces apoptosis of human HS-sultan cells accompanied by activation of caspase-3 and down-regulation of ERK pathways. Am. J. Hematol. 2005, 78, 7-14. [CrossRef]

24. Banafa, A.M.; Roshan, S.; Liu, Y.-Y.; Chen, H.-J.; Chen, M.-J.; Yang, G.-X.; He, G.-Y. Fucoidan induces G1 phase arrest and apoptosis through caspases-dependent pathway and ROS induction in human breast cancer MCF-7 cells. J. Huazhong Univ. Sci. Technol. 2013, 33, 717-724. [CrossRef]

25. Ishikawa, C.; Mori, N. In Vitro and In Vivo anti-primary effusion lymphoma activities of fucoidan extracted from Cladosiphon okamuranus Tokida. Oncol. Rep. 2017, 38, 3197-3204. [CrossRef]

26. Han, Y.-S.; Lee, J.H.; Lee, S.H. Antitumor effects of fucoidan on human colon cancer cells via activation of Akt signaling. Biomol. Ther. 2015, 23, 225-232. [CrossRef]

27. Gazha, A.K.; Zaporozhets, T.S.; Kuznetsova, T.A.; Zvyaguintseva, T.N.; Besednova, N.N. Effect of sulfated polysaccharides from brown algae on apoptosis of human peripheral blood lymphocytes. Bull. Exp. Biol. Med. 2015, 159, 617-619. [CrossRef]

28. Boo, H.-J.; Hong, J.-Y.; Kim, S.-C.; Kang, J.-I.; Kim, M.-K.; Kim, E.-J.; Hyun, J.-W.; Koh, Y.-S.; Yoo, E.-S.; Kwon, J.-M.; et al. The anticancer effect of fucoidan in PC-3 prostate cancer cells. Mar. Drugs 2013, 11, 2982-2999. [CrossRef]

29. Ale, M.T.; Maruyama, H.; Tamauchi, H.; Mikkelsen, J.D.; Meyer, A.S. Fucoidan from Sargassum sp. and Fucus vesiculosus reduces cell viability of lung carcinoma and melanoma cells In Vitro and activates natural killer cells in mice In Vivo. Int. J. Biol. Macromol. 2011, 49, 331-336. [CrossRef]

30. Vishchuk, O.S.; Ermakova, S.P.; Zvyagintseva, T.N. The fucoidans from brown algae of Far-Eastern seas: Anti-tumor activity and structure-function relationship. Food Chem. 2013, 141, 1211-1217. [CrossRef]

31. Lühn, S.; Schrader, T.; Sun, W.; Alban, S. Development and evaluation of a fluorescence microplate assay for quantification of heparins and other sulfated carbohydrates. J. Pharm. Biomed. Anal. 2010, 52, 1-8. [CrossRef]

32. Lühn, S.; Grimm, J.C.; Alban, S. Simple and rapid quality control of sulfated glycans by a fluorescence sensor assay-exemplarily developed for the sulfated polysaccharides from red algae Delesseria sanguinea. Mar. Drugs 2014, 12, 2205-2227. [CrossRef]

33. Deniaud-Bouët, E.; Kervarec, N.; Michel, G.; Tonon, T.; Kloareg, B.; Hervé, C. Chemical and enzymatic fractionation of cell walls from Fucales: Insights into the structure of the extracellular matrix of brown algae. Ann. Bot. 2014, 114, 1203-1216. [CrossRef]

34. Ehrig, K.; Alban, S. Sulfated galactofucan from the brown alga Saccharina latissimi_-variability of yield, structural composition and bioactivity. Mar. Drugs 2014, 13, 76-101. [CrossRef]

35. Zhang, Z.; Teruya, K.; Eto, H.; Shirahata, S. Fucoidan extract induces apoptosis in MCF-7 cells via a mechanism involving the ROS-dependent JNK activation and mitochondria-mediated pathways. PLoS ONE 2011, 6, e27441. [CrossRef]

36. Dithmer, M.; Kirsch, A.-M.; Richert, E.; Fuchs, S.; Wang, F.; Schmidt, H.; Coupland, S.E.; Roider, J.; Klettner, A. Fucoidan does not exert anti-tumorigenic effects on uveal melanoma cell lines. Mar. Drugs 2017, 15, 193. [CrossRef]

37. Roshan, S.; Liu, Y.-Y.; Banafa, A.; Chen, H.-J.; Li, K.-X.; Yang, G.-X.; He, G.-Y.; Chen, M.-J. Fucoidan induces apoptosis of HepG2 cells by down-regulating p-Stat3. J. Huazhong Univ. Sci. Technol. 2014, 34, 330-336. [CrossRef]

38. Park, H.S.; Hwang, H.J.; Kim, G.-Y.; Cha, H.-J.; Kim, W.-J.; Kim, N.D.; Yoo, Y.H.; Choi, Y.H. Induction of apoptosis by fucoidan in human leukemia U937 cells through activation of p38 MAPK and modulation of Bcl-2 family. Mar. Drugs 2013, 11, 2347-2364. [CrossRef] 
39. Jin, J.-O.; Song, M.-G.; Kim, Y.-N.; Park, J.-I.; Kwak, J.-Y. The mechanism of fucoidan-induced apoptosis in leukemic cells:Involvement of ERK1/2, JNK, glutathione, and nitric oxide: Involvement of ERK1/2, JNK, glutathione, and nitric oxide. Mol. Carcinog. 2010, 49, 771-782.

40. Atashrazm, F.; Lowenthal, R.M.; Woods, G.M.; Holloway, A.F.; Dickinson, J.L. Fucoidan and cancer: A multifunctional molecule with anti-tumor potential. Mar. Drugs 2015, 13, 2327-2346. [CrossRef]

41. Somasundaram, S.N.; Shanmugam, S.; Subramanian, B.; Jaganathan, R. Cytotoxic effect of fucoidan extracted from Sargassum cinereum on colon cancer cell line HCT-15. Int. J. Biol. Macromol. 2016, 91, 1215-1223. [CrossRef]

42. Ben-David, U.; Siranosian, B.; Ha, G.; Tang, H.; Oren, Y.; Hinohara, K.; Strathdee, C.A.; Dempster, J.; Lyons, N.J.; Burns, R.; et al. Genetic and transcriptional evolution alters cancer cell line drug response. Nature 2018, 560, 325-330. [CrossRef]

43. Atashrazm, F.; Lowenthal, R.M.; Woods, G.M.; Holloway, A.F.; Karpiniec, S.S.; Dickinson, J.L. Fucoidan Suppresses the Growth of Human Acute Promyelocytic Leukemia Cells In Vitro and In Vivo. J. Cell. Physiol. 2016, 231, 688-697. [CrossRef]

44. Li, X.; Zhao, H.; Wang, Q.; Liang, H.; Jiang, X. Fucoidan protects ARPE-19 cells from oxidative stress via normalization of reactive oxygen species generation through the $\mathrm{Ca}^{2+}$-dependent ERK signaling pathway. Mol. Med. Rep. 2015, 11, 3746-3752. [CrossRef]

45. Zemani, F.; Benisvy, D.; Galy-Fauroux, I.; Lokajczyk, A.; Colliec-Jouault, S.; Uzan, G.; Fischer, A.M.; Boisson-Vidal, C. Low-molecular-weight fucoidan enhances the proangiogenic phenotype of endothelial progenitor cells. Biochem. Pharmacol. 2005, 70, 1167-1175. [CrossRef]

46. Wang, Z.-J.; Xu, W.; Liang, J.-W.; Wang, C.-S.; Kang, Y. Effect of fucoidan on B16 murine melanoma cell melanin formation and apoptosis. Afr. J. Tradit. Complement. Altern. Med. 2017, 14, 149-155. [CrossRef]

47. Ale, M.T.; Maruyama, H.; Tamauchi, H.; Mikkelsen, J.D.; Meyer, A.S. Fucose-containing sulfated polysaccharides from brown seaweeds inhibit proliferation of melanoma cells and induce apoptosis by activation of caspase-3 In Vitro. Mar. Drugs 2011, 9, 2605-2621. [CrossRef]

48. Park, H.Y.; Park, S.-H.; Jeong, J.-W.; Yoon, D.; Han, M.H.; Lee, D.-S.; Choi, G.; Yim, M.-J.; Lee, J.M.; Kim, D.-H.; et al. Induction of p53-independent apoptosis and G1 cell cycle arrest by fucoidan in HCT116 human colorectal carcinoma cells. Mar. Drugs 2017, 15, 154. [CrossRef]

49. Zhurishkina, E.V.; Stepanov, S.I.; Shvetsova, S.V.; Kulminskaya, A.A.; Lapina, I.M. A comparison of the effect of fucoidan from alga Fucus vesiculosus and its fractions obtained by anion-exchange chromatography on HeLa G-63, Hep G2, and Chang liver cells. Cell Tissue Biol. 2017, 11, 242-249. [CrossRef]

50. Ryu, M.J.; Chung, H.S. Fucoidan reduces oxidative stress by regulating the gene expression of HO-1 and SOD-1 through the Nrf2/ERK signaling pathway in HaCaT cells. Mol. Med. Rep. 2016, 14, 3255-3260. [CrossRef]

51. Alwarsamy, M.; Gooneratne, R.; Ravichandran, R. Effect of fucoidan from Turbinaria conoides on human lung adenocarcinoma epithelial (A549) cells. Carbohydr. Polym. 2016, 152, 207-213. [CrossRef]

52. Huang, T.-H.; Chiu, Y.-H.; Chan, Y.-L.; Chiu, Y.-H.; Wang, H.; Huang, K.-C.; Li, T.-L.; Hsu, K.-H.; Wu, C.-J. Prophylactic administration of fucoidan represses cancer metastasis by inhibiting vascular endothelial growth factor (VEGF) and matrix metalloproteinases (MMPs) in Lewis tumor-bearing mice. Mar. Drugs 2015, 13, 1882-1900. [CrossRef]

53. Bobiński, M.; Okła, K.; Bednarek, W.; Wawruszak, A.; Dmoszyńska-Graniczka, M.; Garcia-Sanz, P.; Wertel, I.; Kotarski, J. The effect of fucoidan, a potential new, natural, anti-neoplastic agent on uterine sarcomas and carcinosarcoma cell lines. Arch. Immunol. Exp. 2019, 67, 125-131. [CrossRef]

54. Kim, E.J.; Park, S.Y.; Lee, J.-Y.; Park, J.H.Y. Fucoidan present in brown algae induces apoptosis of human colon cancer cells. BMC Gastroenterol. 2010, 10, 96. [CrossRef]

55. Park, H.S.; Kim, G.-Y.; Nam, T.-J.; Deuk Kim, N.; Hyun Choi, Y. Antiproliferative activity of fucoidan was associated with the induction of apoptosis and autophagy in AGS human gastric cancer cells. J. Food Sci. 2011, 76, T77-T83. [CrossRef]

56. Yang, G.; Zhang, Q.; Kong, Y.; Xie, B.; Gao, M.; Tao, Y.; Xu, H.; Zhan, F.; Dai, B.; Shi, J.; et al. Antitumor activity of fucoidan against diffuse large B cell lymphoma in vitro and in vivo. Acta Biochim. Biophys. Sin. 2015, 47, 925-931. [CrossRef] 
57. Dreyfuss, J.L.; Regatieri, C.V.; Lima, M.A.; Paredes-Gamero, E.J.; Brito, A.S.; Chavante, S.F.; Belfort, R.; Farah, M.E.; Nader, H.B. A heparin mimetic isolated from a marine shrimp suppresses neovascularization. J. Thromb. Haemost. 2010, 8, 1828-1837. [CrossRef]

58. Shastri, M.D.; Stewart, N.; Horne, J.; Peterson, G.M.; Gueven, N.; Sohal, S.S.; Patel, R.P. In-Vitro suppression of IL-6 and IL-8 release from human pulmonary epithelial cells by non-anticoagulant fraction of enoxaparin. PLoS ONE 2015, 10, e0126763. [CrossRef]

59. Solayar, G.N.; Walsh, P.M.; Mulhall, K.J. The effect of a new direct Factor Xa inhibitor on human osteoblasts: An In-Vitro study comparing the effect of rivaroxaban with enoxaparin. BMC Musculoskelet. Disord. 2011, 12, 247. [CrossRef]

60. Lean, Q.Y.; Patel, R.P.; Stewart, N.; Sohal, S.S.; Gueven, N. Identification of pro-and anti-proliferative oligosaccharides of heparins. Integr. Biol. 2014, 6, 90-99. [CrossRef]

61. Uzun, Y.; Akdogan, E.; Ozdemir, F.; Ovali, E. The effects of heparin on DLD-1 colon cancer cell line. Bratisl. Lek. Listy 2009, 110, 3-6.

62. Bohlmann, M.K.; Hoerster, J.-C.; Bundschuh, D.; Boemicke, P.; Luedders, D.W.; Köster, F. Growth-modulatory effects of heparin and VEGF-165 on the choriocarcinoma cell-line JEG-3 and its expression of heparanase. Anticancer Res. 2014, 34, 7071-7076.

63. Ueda, K.; Inoue, S.; Zhang, Y.; Kutsuna, T.; Inoue, S.; Noto, K.; Arai, N.; Noguchi, M. Heparin induces apoptosis through suppression of AKt in oral squamous cell carcinoma cells. Anticancer Res. 2009, 29, 1079-1088.

64. Nagarajan, A.; Malvi, P.; Wajapeyee, N. Heparan sulfate and heparan sulfate proteoglycans in cancer initiation and progression. Front. Endocrinol. 2018, 9, 483. [CrossRef]

65. Vicente, C.M.; da Silva, D.A.; Sartorio, P.V.; Silva, T.D.; Saad, S.S.; Nader, H.B.; Forones, N.M.; Toma, L. Heparan sulfate proteoglycans in human colorectal cancer. Anal. Cell. Pathol. 2018, 2018, 8389595. [CrossRef]

66. Saad, A.; Liet, B.; Joucla, G.; Santarelli, X.; Charpentier, J.; Claverol, S.; Grosset, C.F.; Trézéguet, V. Role of glycanation and convertase maturation of soluble glypican-3 in inhibiting proliferation of hepatocellular carcinoma cells. Biochemistry 2018, 57, 1201-1211. [CrossRef]

67. Porcionatto, M.A.; Nader, H.B.; Dietrich, C.P. Heparan sulfate and cell division. Braz. J. Med. Biol. Res. 1999, 32, 539-544. [CrossRef]

68. Ale, M.T.; Meyer, A.S. Fucoidans from brown seaweeds: An update on structures, extraction techniques and use of enzymes as tools for structural elucidation. RSC Adv. 2013, 3, 8131-8141. [CrossRef]

69. Yuan, Y.V.; Walsh, N.A. Antioxidant and antiproliferative activities of extracts from a variety of edible seaweeds. Food Chem. Toxicol. 2006, 44, 1144-1150. [CrossRef]

70. Lahrsen, E.; Schoenfeld, A.-K.; Alban, S. Size-dependent pharmacological activities of differently degraded fucoidan fractions from Fucus vesiculosus. Carbohydr. Polym. 2018, 189, 162-168. [CrossRef]

71. Lahrsen, E.; Schoenfeld, A.-K.; Alban, S. Degradation of eight sulfated polysaccharides extracted from red and brown algae and its impact on structure and pharmacological activities. ACS Biomater. Sci. Eng. 2019, 5, 1200-1214. [CrossRef]

(C) 2019 by the authors. Licensee MDPI, Basel, Switzerland. This article is an open access article distributed under the terms and conditions of the Creative Commons Attribution (CC BY) license (http://creativecommons.org/licenses/by/4.0/). 